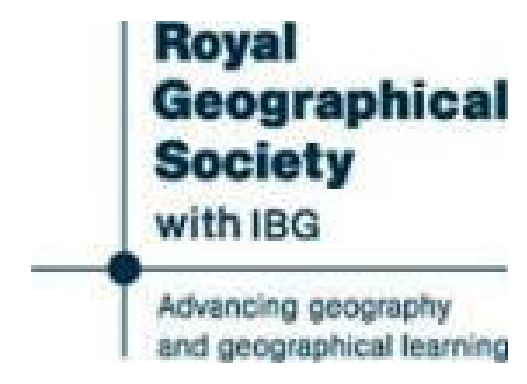

M. Marcel Dubois on Colonial Systems and Colonizing Peoples Systèmes Coloniaux et Peuples Colonisateurs. Dogmes et Faits Review by: G. G. Chisholm

The Geographical Journal, Vol. 7, No. 2 (Feb., 1896), pp. 193-195

Published by: The Royal Geographical Society (with the Institute of British Geographers)

Stable URL: http://www.jstor.org/stable/1773731

Accessed: 08/01/2015 19:01

Your use of the JSTOR archive indicates your acceptance of the Terms \& Conditions of Use, available at http://www.jstor.org/page/info/about/policies/terms.jsp

JSTOR is a not-for-profit service that helps scholars, researchers, and students discover, use, and build upon a wide range of content in a trusted digital archive. We use information technology and tools to increase productivity and facilitate new forms of scholarship. For more information about JSTOR, please contact support@jstor.org. 
be correct. In connection with Colossai, there are good descriptions of the old Eastern Highway, and of the later Byzantine road to the east, which, instead of following the old road to Apameia, turned north to the Mæander valley, near Siblia, and crossed the hills beyond it by the Duz Bel.

Some of the most interesting passages in the book are those that relate to the imperial estates in the Killanian plain. These estates were farmed to contractors, and were managed by a procurator who was an imperial freedman, and managers who were imperial slaves. The land was cultivated by the natives, who paid rent for their farms. The procurator, who represented the imperial authority, maintained public order by a corps of police, and marked and preserved the boundaries of the properties. The estates appear to have belonged to the Pergamenian kings, from whom they passed to the Roman emperors. At a later period they came into the hands of a branch of the imperial family, and they seem to have been owned by the Annia Faustina who married the Emperor Elagabalus.

It may be added that each chapter of Prof. Ramsay's book is followed by appendices, containing the more important inscriptions in the district described, lists of the bishops, and discussions on disputed points. There is also a clear map, showing the natural features and the ancient sites in South-Western Phrygia. In transliterating Turkish words, the adoption of the French form $d j$ for $j$, and $t c h$ for $c h$, is, we think, to be regretted.

Prof. Ramsay's 'Local History of Phrygia' will, we venture to think, when completed, be the most important work of the kind that has been published in this country in recent times; and the thanks of geographers and scholars alike are due to the delegates of the Clarendon Press for undertaking its publication.

\title{
M. MARCEL DUBOIS ON COLONIAL SYSTEMS AND COLONIZING PEOPLES.*
}

\author{
By G. G. CHISHOLM, M.A., B.Sc.
}

THIs work is in a large measure avowedly polemical. It is called forth by the author's conviction of the erroneous nature of some of the views expressed, more particularly of M. P. Leroy-Beaulieu in his 'History of Modern Colonization,' as well as of Seeley and his French translator M. Rambaud. M. Dubois wishes especially to protest against the current belief that the French are not a colonizing nation, and that their failure is due, like that of many other nations, to the inferiority of their methods as compared with the liberal policy to which England owes her success

\footnotetext{
* 'Systèmes Coloniaux et Peuples Colonisateurs. Dogmes et Faits.' Paris: G. Masson, 1895.
} 
in colonization. M. Dubois maintains, on the contrary, that the French are eminently a colonial people; that they have even found out the mode of expansion truly useful to their country and truly moral (vraiment moral); and as regards the liberality of the English policy-held up, he says, especially by some of his own countrymen as an example to the French-he asserts that such liberality as England has shown was forced upon her by circumstances, and that, historically, the French were in advance of the English in the application of liberal ideas to colonial management. Originally, English colonization was carried out from exactly the same motive as that which animated other countries-the desire to secure a monopoly of trade. Self-government was granted to some of our colonies only to avoid a similar secession to that by which we lost the United States.

These and other ideas are developed in a series of chapters in which a sketch is given of the colonizing efforts of all the leading colonial nations of modern times, beginning with Portugal. The territorial expansion of Russia is treated from the same point of view in one chapter, and that of the United States in another headed "Colonies of Colonies." These chapters are all very interesting, and are crowded with just remarks, though a good deal is demonstrated with somewhat of the air of discovery that is pretty obvious to all students of colonial history.

We are glad to see that this volume is only a preliminary survey of the question, issued now because the author believes that a protest against current ideas is urgently required, and that he hopes afterwards to present the results of his studies to the public in a more rigorous form, in which his theses shall be supported by documents and proofs. That being so, it may be of use to direct attention to certain oversights or doubtful statements that it would be well to examine before the more extended work is issued. Perhaps the most curious of the oversights is the enumeration (p. 118) of the Channel Islands among the annexations of England between the peace of Utrecht and 1815. In the Channel Islands it is not forgotten that such annexation as there was took place the other way and at a much earlier date.

That, however, will mislead no one; but there are some other statements that require more attention. M. Dubois again and again insists that the population of the United States is not English in origin in so large a proportion as we are apt to suppose. On p. 108 he says that down to 1640 , when emigration was arrested or slackened in consequence of the cessation of religious persecution in England, only from 25,000 to 30,000 exiles crossed the Atlantic, and that, as in 1660 there were nearly 200,000 Europeans in the American colonies, it may be assumed (il est permis de croire) that the English then did not form the majority, but that already they were becoming fused with Irish, Dutch, Swedes, and French into a new family. We hope that in the more extended work the grounds for this assumption will be given. 
Speaking of New England only, Seeley ('Expansion of England,' p.71), citing Hildreth's 'History of the United States,'states that the immigrants to that region down to 1640 were not more than 25,000 , and that after that date the immigration was balanced by emigration "or dispersion "; but he adds that from these 25,000 are derived not less, perhaps, than one-fourth of the present population of the United States, leaving us to suppose that the net gain from the early immigration into the American colonies from all quarters subsequent to 1640 did not count for much. But Charles Davenant, one of the most careful statistical investigators of the seventeenth century, writing in 1698 , states that for the past eighty years the plantations are admitted to have carried away in ordinary years about 1000 persons. He is estimating the loss of England alone by emigration, and if there is any truth in this estimate, it should be taken into account in such calculations.

Further on (p. 117) M. Dubois states in a note that the great stream of emigration to the United States, begun in 1815, has not been exclusively English. That, of course, is quite true, even if English be taken to include Irish; but M. Dubois adds the extraordinary and of course utterly erroneous statement, that between 1821 and 1881 the number of Italians that went to the United States was three times as great as that of the English. Again, speaking of the concentration of the population of the United States in towns, M. Dubois (p. 200) states that in Illinois, Chicago absorbs the whole of the increase of the population. Well, it is true that between 1880 and 1890 the great bulk of the increase of the state of Illinois belonged to Chicago, but the very rough way of stating this adopted by M. Dubois conceals facts worthy of careful consideration. The truth is, that during the same period the increase of population in Illinois, apart from Chicago, was about 150,000 on a total initial population of $2,575,000$, equal to an annual increase of 5.7 per 1000, more than three times the rate for the same period in France, urban and rural population included.

\section{DR. SVEN HEDIN IN CENTRAL ASIA.*}

[The following has been received from Dr. Sven Hedin, under date “Kashgar, October 20, 1895."]

I will briefly relate my proceedings during the past summer. On July 10, I started viâ the village of Upale to the Ulug-art pass over the Kashgar range (Mustag), which proved the most difficult of all the passes that I know. Water boiled at $83.69^{\circ} \mathrm{C}$. $\left(172 \cdot 66^{\circ} \mathrm{Fahr}\right.$.), with an air-temperature of $1.8^{\circ}$ ( $35^{\circ}$ Fahr.), snow falling at the time. It is not the altitude, but the nature of the ground which makes the pass so

* A further long communication has been received from Dr. Hedin, which will be published in an early number. 